\title{
The Effect Of Profitability, Value, Size and Managerial Discretion On Disclourse Of Stock Return
}

\author{
Santi Yustini, Yusar Sagara, Anis Saputri \\ Universitas Islam Negeri Syarif Hidayatullah Jakarta \\ santi.yustini@uinjkt.ac.id; yusar.sagara@uinjkt.ac.id; anis.saputri@gmail.com
}

\begin{abstract}
The objective of this study is to examine the effect of profitability that proxied by return on net operating assets and total asset turnover. Valuation is proxied by the price to book value. Size is proxied by total assets and Managerial Discretion is proxied by CEO Tenure. The analytical method used in this study is regression of bunches. The samples of this study are listed companies in property, real estate, and building construction that actively trading between 2013 until 2015 in Indonesia Stock Exchange.The results of this study indicate that the variable return on net operating assets, price to book value, size has a positive influence on the disclosure of stock return, while the total asset turnover and CEO tenure has no effect on the disclosure of stock return.
\end{abstract}

Keywords: Return on net operating assets (RNOA), Total asset turnover (TATO), Price to book value (PBV), Size, CEO Tenure, Managerial Discretion, Stock Return

\begin{abstract}
Abstrak
Tujuan dari penelitian ini adalah untuk menguji pengaruh profitabilitas yang ditunjukkan oleh pengembalian aset operasi bersih dan perputaran total aset. Penilaian ditunjukkan dengan nilai buku. Ukuran ditunjukkan dengan total aset dan kebijakan manajer ditunjukkan oleh masa jabatan CEO. Metode analisis yang digunakan dalam penelitian ini adalah regresi berganda. Sampel penelitian ini adalah perusahaan yang terdaftar di bidang properti, real estat, dan konstruksi bangunan yang masih aktif tahun 2013 hingga 2015 di Bursa Efek Indonesia. Hasil penelitian ini menunjukkan bahwa variabel pengembalian asset operasi bersih, nilai buku dan ukuran memiliki pengaruh positif terhadap pengungkapan pengembalian saham, sedangkan perputaran total aset dan masa jabatan CEO tidak berpengaruh terhadap pengungkapan pengembalian saham.

Kata kunci: Pengembalian Aset Operasi Bersih, Perputaran Total Aset, Harga Nilai Buku, Ukuran Perusahaan, Masa Jabatan CEO, Diskresi Manajerial, Pengembalian Saham
\end{abstract}

Diterima: 9 Agustus 2018; Revisi: 2018; Disetujui: 2018 


\section{INTRODUCTION}

In investing, revenue (return) is one of the factors that may affect the investor in making an investment decision (Ismanto, 2011), According toWalace and Zinkin (2005:281). The main interest of shareholder is the return of the company's productivity, in this case dividend and stock appreciation. Some cases of companies that declined drastically stock average about over $40 \%$ occurred in 2014, even company Bumi Resources has decreased by 94.06\% (Melani, 2014). It was indicated that all the cases occurs because of there are several factors that affect stock prices, such as the fundamental factors, bad performance of companies that lead the company suffered a loss or reduction in income, bad corporate governance, management policy about assets, liabilities and capitalization. Therefore, it is necessary for investors to evaluate the company'sperformance, governance, management, and characteristics of the company as well as things that are informative to investors in order to assist in making decision.

To evaluatecompany performance, investors require information of an entity, which is the financial report. The objective of financial reporting is to provide financial information about an entity that is useful to investors in making investment decision (Kiseo et al. 2011: 7), from many factors that influencing the stock price performance, the researchers took fundamental factors which were derived from the information disclosed in the company's financial statements and annual reports such as profitability ratios measured with return on net operating assets (RNOA) and total assets turnover (TATO), the ratio of valuation measured by the price to book value (PBV), firm size measured by total asset which is the company information as part of other financial information. Then the element of Managerial Discretion was proxied by CEO tenure.

Based on the above explanation that motivated to do research because first, there were phenomena of stock prices declining, and many of them caused by fundamental factors of financial statements that indicated may affect the performance of the stock price. Second, there is still a lack of studies using the proxy Return On Net Operating Assets in measuring the performance of the company's profitability, especially in measuring the performance of the operating 
assets. Third, previous studies still give inconsistent results. This study is an extension of previous research, the research done by (Sparta, 2011), (Papanastasopoulos et al. 2016), (Abdullah, 2016), (Martani, et al., 2009), (Mohammed et al. 2014), (Friedman et al. 1989), This study aimed to analyze the causality that is used to describe the effect of profitability, valuation, Size, and Managerial Discretion Against Disclosure of Stock Return.

\section{METHODS}

The population of this research is Real Estate, Property and Building Construction company listed in Indonesia Stock Exchange for three years period from 2013 to 2015 . Focus of the study wanted to see the effect of profitability was proxied by return on net operating asset and total asset turnover, valuation was proxied by the price to book value, size (the total asset of the company), and managerial discretion was proxied by CEO Tenure on the disclosure of stock return.

In this study, the method used to select the sample is purposive sampling with a particular type of consideration (judgment sampling). Consideration sampling criteria companies in this study as follow:

Table 1. Sample Data Research

\begin{tabular}{|r|l|c|}
\hline No. & \multicolumn{1}{|c|}{ Sample Selection Criteria } & Amount \\
\hline 1 & $\begin{array}{l}\text { Property real estate and building construction } \\
\text { companies which is consistently listed shares } \\
\text { for three years at the Indonesia Stock } \\
\text { Exchange in 2013-2015 }\end{array}$ & 48 \\
\hline 2 & $\begin{array}{l}\text { Companies that suffer from operating losses } \\
\text { for the year 2013 to 2015 }\end{array}$ & $(8)$ \\
\hline 3 & Companies that enter the number of samples & 40 \\
\hline 4 & The total sample for 3 years & $\mathbf{1 2 0}$ \\
\hline 5 & Outliers (Casewise) & $\mathbf{1 4}$ \\
\hline 6 & Total Samples & $\mathbf{1 1 6}$ \\
\hline
\end{tabular}

Source: Data processed

Based on the table above, it can be seen that the samples used in this study amounted to 40 companies. The sample is selected because it has met the criteria 
determined in accordance with the needs of the research analysis. However, because there are four samples that outlier, then samples consist of 116.

RNOA (Return On Net Operating Assets) is defined as net operating profit after tax (net operating profit after tax - NOPAT) divided by the net asset operations (net operating assets - NOA), RNOA illustrates the yields of the utilization of the operating assets in generating profits and contains components of corporate performance. Measurements on RNOA is a useful to analyze the profitability of a company(Subramanyam and Wild, 2011),

$$
R N O A=\frac{\text { Net Operating Profit After Tax }}{\text { Net Operating Assets }}
$$

NOPAT (Net Operating Profit After Tax) is net income after taxes that generated from net operating assets, the net operating profit including sales minus cost of goods sold, operating expense such as selling, general and administrative, as well as income tax. The posts are excluded from NOPAT including interest income and expense, dividend income, gains and losses of non-operating investments, as well as the profit or loss from discontinued operations (all calculated net of tax)Subramanyam and Wild (2011: 150-151), Researchers used measurements formulated by(Sparta 2011) as follows:

$$
\text { NOPAT }=(\text { Sales }- \text { Operating Expense }) X\left(1-\frac{\text { Tax Expense }}{\text { Pretax Profit }}\right)
$$

Net Operating Assets (NOA) is measured as the difference between the operating assets and operating liabilities (Sparta, 2011). Operating Asset is a residual value of total assets after deducting cash and cash equivalents. Operating Liabilities is the residual value of the total assets after deducting minority interest, ordinary and preferred share and total debt. According to (Penman, 2007) in (Papanastasopoulos et al. 2011). Operating liabilities incurred as part of the operation, while the financial liabilities incurred as part of financing activities to raise cash in running the business. NOA then formulated (Papanastasopoulos and Thomakos, 2016):

$$
\text { NOA }=\text { Operating Asset }- \text { Operating Liabilities }
$$


Total Asset Turnover is a ratio used to measure the velocity of all assets owned by the company and measure how many sales were obtained from each rupiah assets (Kashmir, 2009: 185)

$$
\text { TATO }=\frac{\text { Sales }}{\text { Total Asset }}
$$

Price to book value is one of the financial ratios in the form of market. The higher ratio of market price to book value, the better the companies rated by investors. This ratio describes the ratio between the market value of the book value of a share(Dance Indriani, 2014),

$$
P B V=\frac{\text { Harga Pasar Per Lembar Saham }}{\text { Nilai Buku Per lembar Saham }}
$$

Size is an information of the company in the form of a big or small company'sreflection. Size related to the ability and opportunity to enter the capital market and to obtain external financing (Yuliantari and Sujana, 2014),The size of the company in the long term is a form of good growth (Widyastuti, 2007), In this study, researchers used a measurement used by(Setiyono, 2016).

\section{FIRM SIZE = Ln total Assets}

To examine the managerial discretion, the author uses the CEO Tenure as a proxy that represents the management's discretion. According to (Wu et al. 2005) and Chen (2013), CEO Tenure play an important role in allocating, organizing and motivating the company's resources and capabilities as well as contribute significantly to empowering productivity. Because the asset is one of the resources of the company, the CEO is entitled to determine the policy and strategy of the asset, particularly in operating activities. CEO Tenure measured by (Karyati, 2014):

\section{CEO Tenure $=$ Ln tenure of a CEO in a company}

Disclosure of stock return is the result that obtained from an investment.It may be a return realization has occurred or return expectations that has not happened. To obtain stock returns and profits as expected, then investor must be able to assess the stock price. Stock prices can affect the magnitude of the return. In this study disclosure of stock return measured byusing the yield on stock prices as practiced by(Abdullah et al. 2016), The measurement as follows: 


$$
\text { Disclosures of Stock Return }=\frac{P t-P t-1}{P t-1}
$$

Information :

$\mathrm{Pt} \quad=$ Stock Price Period Research

Pt-1 = Stock Price Prior Period Research

The equation to test the hypothesis in this study are as follows:

Disclosure of Stock Return $=\alpha+\beta 1 \mathrm{RNOA}+\beta 2 \mathrm{TATO}+\beta 3 \mathrm{PBV}+\beta 4 \mathrm{SIZE}+$ $\beta 5 C E O T+\varepsilon$

Where:

Stock Disclosure Return Annual Return = Stock; RNOA = Return On Net Assets Operrating; TATO = Total Assets Turnover; PBV = Price to Book Value; SIZE = Size Company; $\mathrm{CEO}$ of $\mathrm{T}=\mathrm{CEO}$ Tenure; $\mathrm{a}=$ Constant; $\beta_{1} \ldots, \beta_{5}=$ coefficient of regression; $\varepsilon=$ Error

\section{RESULTS AND DISCUSSION}

Normality test can be performed to determine whether in a regression model, the dependent variable and the independent variables were normally distributed or not. If this assumption is violated, the statistical test is not valid.

Figure 1

\section{Normality Test Results P-Plot Graphs}

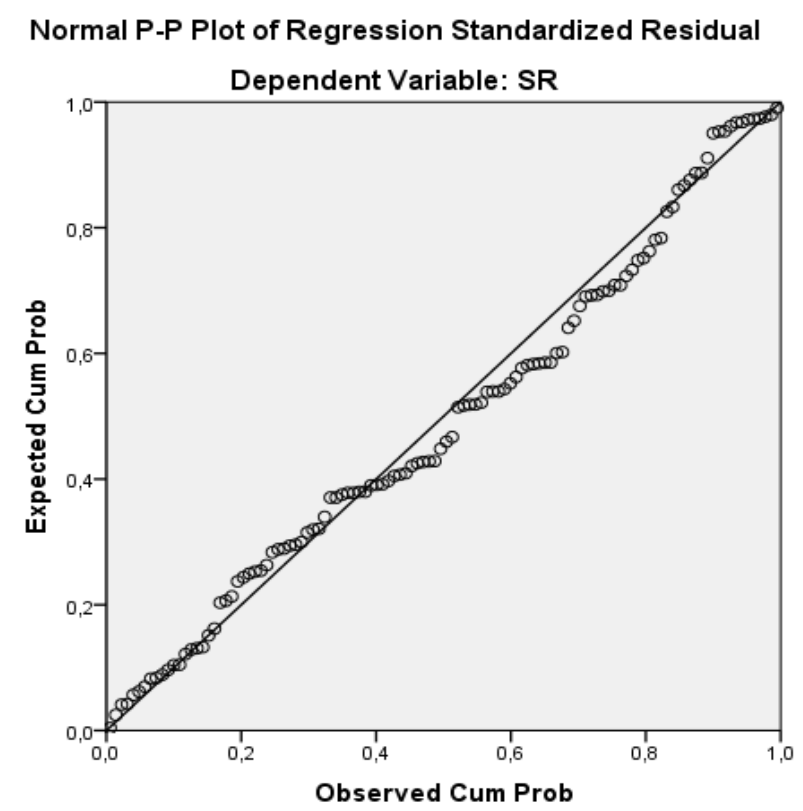


From Picture 1 shows that the research data have a normal distribution and distribution since spread around the diagonal line, and the distribution does not move away from the diagonal line. It shows a normal distribution pattern.

Table 2 One Sample Test Results Statistics Kolmogorov

\begin{tabular}{llr}
\hline & & \multicolumn{2}{c}{$\begin{array}{c}\text { Residual } \\
\text { unstandardized }\end{array}$} \\
\hline $\mathrm{N}$ & mean &, 0000000 \\
Normal Parameters ${ }^{\mathrm{a}, \mathrm{b}}$ & Std. deviation &, 39644311 \\
& Absolute &, 077 \\
Most Extreme Differences & positive &, 077 \\
& negative &,- 057 \\
Test Statistic & &, 077 \\
Asymp. Sig. (2-tailed) & &, $090 \mathrm{c}$
\end{tabular}

From table 2 it can be seen that the value of the Kolmogorov Smirnov is 0.077 and the value Asymp Sig (2-tailed) significant at the $0.090>0.05$ this means data residuals are normally distributed.

Multicoloniarity test is done by calculating the value of tolerance and VIF (Variance Inflation Factor). If the tolerance values $>0.10$ and VIF $<10$ then can be expressed freely multikolonearitas. Based on the SPSS $22 \mathrm{v}$ results, it obtained value tolerance and VIF in table 3. Thus it can be said that the regression model is free of multicoloniarity.

Table 3 MultikoliniearityTest Results

\begin{tabular}{|c|c|c|c|c|c|c|c|c|}
\hline \multirow[b]{3}{*}{ Model } & \multirow{2}{*}{\multicolumn{2}{|c|}{$\begin{array}{c}\text { Coefficients } \\
\text { Unstandardized }\end{array}$}} & \multirow{3}{*}{$\begin{array}{c}\begin{array}{c}\text { Standardized } \\
\text { Coefficients }\end{array} \\
\text { beta }\end{array}$} & \multirow[b]{3}{*}{$\mathrm{T}$} & \multirow[b]{3}{*}{ Sig. } & \multirow{2}{*}{\multicolumn{2}{|c|}{$\begin{array}{l}\text { Collinearity } \\
\text { Statistics }\end{array}$}} & \\
\hline & & & & & & & & \\
\hline & B & Std. Error & & & & Tolerance & VIF & \\
\hline \multicolumn{2}{|c|}{ (Constant) } & -1.243 &, 377 & & -3.297 & .001 & & \\
\hline \multicolumn{2}{|l|}{ RNOA } &, 023 & .011 &, 169 & 2,191 &, 031 &, 972 & 1.029 \\
\hline \multicolumn{2}{|c|}{ TATTOOS } &, 106 & , 111 &, 074 &, 948 &, 345 &, 943 & 1,060 \\
\hline \multicolumn{2}{|l|}{ PBV } &, 180 &, 027 &, 527 & 6.729 &, 000 &, 949 & 1,054 \\
\hline
\end{tabular}




\begin{tabular}{llllllll} 
LnTA (SIZE) &, 028 &, 012 &, 188 & 2.383 & .019 &, 931 & 1.074 \\
LnCEOT &, 054 &, 032 &, 134 & 1,683 &, 095 &, 920 & 1,087 \\
\hline
\end{tabular}

Good regression model is free of autocorrelation. Detection of the autocorrelation can be seen from the significant value Run Test. Based on Table 4 shows that the value of the test is with a probability of $0.136-0.04698$ far above the significant value of 0.05 , it can be said free of autocorrelation.

A good regression model is that homoskedastisitas or not occur heteroscedasticity. To detect the presence or absence of heteroscedasticity with glejser test. From Table 5 shows all the variables have a significance value of 0.05 , which means none of the independent variables are statistically significant affect the dependent variable absolute value of residuals.

Table 4 Autocorrelation Test Results

\begin{tabular}{lr}
\hline & Residual Unstandardized \\
\hline Test Value & a \\
Cases $<$ Test Value & 58698 \\
Cases $>$ = Test Value & 58 \\
total Cases & 116 \\
Number of Runs & 67 \\
Z & 1,492 \\
Asymp. Sig. (2-tailed) &, 136 \\
\hline
\end{tabular}

The test results in Table 6 shows that the $\mathrm{R}^{2}$ of 0.361 or $36.1 \%$. So it can be said that the disclosure amounted to $36.1 \%$ stock return on real estate property and building constructioncompanies listed in Indonesia Stock Exchange 20132015 period due to the return on net operating assets, total asset turnover, price to book value, size, and CEO tenure. While the disclosure amounted to $63.9 \%$ stock return is caused by other variables and not examined in this study. According to the table 7 below, the $t$ test.

The results of regression analysis showed that the return on net operating assets (RNOA) having asignificant effect on the disclosure of stock return. This can be explained by the amount of variable significance level of $0.031<0.05$. The results support the research conducted by (Sparta, 2011) and literature expressed 
by (Subramanyam and Wild, 2011) which states that RNOA is the relevant information in determining the stock price performance.

Table 5 Test Results Heteroskidastity (Glejser Test)

\begin{tabular}{|c|c|c|c|c|c|c|}
\hline \multirow{2}{*}{\multicolumn{2}{|c|}{ Model }} & \multicolumn{2}{|c|}{$\begin{array}{c}\text { Coefficients } \\
\text { unstandardized }\end{array}$} & \multirow{2}{*}{$\begin{array}{c}\text { standardized } \\
\text { Coefficients } \\
\text { beta }\end{array}$} & \multirow[b]{2}{*}{$\mathrm{t}$} & \multirow[b]{2}{*}{ Sig. } \\
\hline & & $B$ & Std. Error & & & \\
\hline \multirow[t]{6}{*}{1} & (Constant) &, 176 &, 231 & &, 762 &, 448 \\
\hline & RNOA & .002 &, 006 &, 036 &, 378 & , 706 \\
\hline & TATTOOS & 029 &, 068 &, 041 & , 425 &, 672 \\
\hline & PBV & .014 & .016 &, 083 &, 861 & , 391 \\
\hline & LnTA (SIZE) &,- 002 &, 007 &,- 025 &,- 254 &, 800 \\
\hline & LnCEOT & .038 &, 020 & , 188 & 1.936 &, 055 \\
\hline
\end{tabular}

The results of regression analysis showed that the total assets turnover (TATO) has not been able to affect the disclosure of stock return. This can be explained by the amount of variable significance level of $0.345>0.05$. The results support the research conducted by(Puspitasari et al. 2017), (Abdullah, 2016) and (Ariyanti, 2016) that TATO can not affect the disclosure of stock return, but is not consistent with the results of research conducted by (Martani et al. 2009), (Najimiyah et al. 2014), (Hayat, 2014),

The results of regression analysis showed that the price to book value (PBV) has positive significant effect on disclosure of stock return. This can be explained by the amount of variable significance level of $0.000<0.05$. The results support the research done by (Muhammad and Scrimgeour, 2014), (Martani et al. 2009) and (Dance Indriani, 2014), But the results inconsistent with (Suherman and Siburian, 2013) and (Najimiyah et al. 2014) studies.

\section{Table 6 Results Coefficient of Determination}

\begin{tabular}{|c|c|c|c|c|c|}
\hline & & & Adjusted R & Std. Error of the & Durbin- \\
\hline Model & $\mathrm{R}$ & R Square & Square & Estimate & Watson \\
\hline 1 & , 601A & 361 & 332 & 4053531 & 2,365 \\
\hline
\end{tabular}

The results of regression analysis showed that the size of the company's has positive significant effecton disclosure of stock return. This can be explained by the 
amount of variable significance level of $0.019<0.05$. The results support the study by (Martani et al.2009), (Ulfa, 2011), (Yuliantari and Sujana, 2014), (Daniel and Titman, 1997) and (Widyastuti, 2007),

Table 7 Individual Parameter Significance Test Results (Test Statistic t)

\begin{tabular}{|c|c|c|c|c|c|}
\hline \multirow[b]{2}{*}{ Model } & \multicolumn{2}{|c|}{$\begin{array}{c}\text { Coefficients } \\
\text { unstandardized }\end{array}$} & \multirow{2}{*}{$\begin{array}{c}\text { standardized } \\
\text { Coefficients } \\
\text { beta }\end{array}$} & \multirow[b]{2}{*}{$\mathbf{t}$} & \multirow[b]{2}{*}{ Sig. } \\
\hline & B & Std. Error & & & \\
\hline 1 (Constant) & -1.243 &, 377 & & -3.297 & .001 \\
\hline RNOA &, 023 & .011 &, 169 & 2,191 &, 031 \\
\hline TATTOOS &, 106 &, 111 &, 074 & , 948 &, 345 \\
\hline PBV &, 180 &, 027 &, 527 & 6.729 &, 000 \\
\hline LnTA (SIZE) &, 028 &, 012 &, 188 & 2.383 & .019 \\
\hline LnCEOT &, 054 &, 032 &, 134 & 1,683 &, 095 \\
\hline
\end{tabular}

The results of regression analysis showed that CEO tenure has not been able to influence the disclosure of stock return. This can be explained by the amount of variable significant level of $0.095>0.05$. The results are consistent with the results of research conducted by (Bhagat et al. 2010) and (Sherif and Leitch, 2017) but is not consistent with the results of research conducted by (Rostami et al. 2016).

\section{CONCLUSION}

It can be concluded that the profitability is proxied by the return on net operating assets (RNOA), the valuation of which is proxied by the price to book value (PBV), size (total asset of the company) is able to affect the disclosure of stock return. While profitability is proxied by total asset turnover (TATO) and managerial doscretion proxied by CEO tenure has not been able to influence the disclosure of stock return.

\section{REFERENCES}

Abdullah, Hilmi. 2016. "Pengaruh Return on Asset (ROA), Debt To Total Asset (DTA) Dan Total Asset Turnover (TATO) Terhadap Return Saham Pada Perusahaan Property Yang Terdaftar Di Bursa Efek Indonesia Tahun 2011- 
2014." 9(2): 1-17.

Abdullah, Hilmi, Soedjatmiko, dan Retno Normala Sari. 2016. “Pengaruh Return On Assets, Debt to Total Asset, dan Total Asset Turnover Terhadap Return Saham." Dinamika Ekonomi Jurnal Ekonomi dan Bisnis 9(September 2016): $1-7$.

Ariyanti, Ajeng Ika. 2016. "Pengaruh CR, TATO, NPM, dan ROA Terhadap Return Saham." Jurnal Ilmu dan Riset Manajemen 5(4).

Bhagat, Sanjai, Brian Bolton, dan Ajay Subramanian. 2010. “CEO Education, CEO Turnover, and Firm Performance." : 1-42.

Chen, Hsiang-Lan. 2013. "CEO Tenure, Independent Directors and Corporate Innovation." Journal of Applied Finance \& Banking 3(5): 187-97. http://www.scienpress.com/Upload/JAFB/Vol 3_5_14.pdf.

Daniel, Kent, dan Sheridan Titman. 1997. "Evidance On The Characteristics of Cross Sectional Variation In Stock Return." The Journal Of Finance LII (March 1997).

Friedman, Stewart D, dan Harbir Singh. 1989. "CEO Succession and Stockholder Reaction: The Influence Of Organizational Context And Event Content." Academy of Management Journal 32(1989): 718-44. http://www.jstor.org/stable/256566.

Hayat, Wahid Al. 2014. "Pengaruh Rasio Keuangan Terhadap Return Saham." Universitas Muhammadiyah Surakarta.

Ismanto, Hadi. 2011. "Analisis Pengaruh Ukuran Perusahaan, Book to Market Value, dan Beta, Terhadap Return Saham di BEI." Jurnal Ekonomi \& Pendidikan, Volume 8 Nomor 2, November 2011 8(November): 164-85.

Jensen, Michael C, dan William H Meckling. 1976. "Theory of the Firm: Managerial.” Journal of Financial Economics 3: 305-60.

Karyati, Titik. 2014. "Pengaruh Kinerja Perusahaan Terhadap Corporate Governance Reporting Dengan Variabel Moderating CEO Tenure." Media Ekonomi dan Manajemen 29(1): 59-67.

Kasmir. 2009. Analisis Laporan Keuangan. 1-2 ed. Jakarta: PT Raja Grafindo 
Persada.

Kiseo, Donald E, Jerry J Weygandt, dan Terry D Warfield. 2011. Intermediate Accounting. Wiley and Sons.

Kusumo, Rm Gian Ismoyo. 2011. Analisis Pengaruh Rasio Keuangan Terhadap Return Saham Pada Perusahaan Non Bank LQ 45.

Martani, Dwi, Mulyono, dan Rahfiani Khairurizka. 2009. "The Effect of Financial Ratio, Firm Size, and Cash Flow From Operating Activities In The Interim Report to the Stock Return." Chinese Business Review 8(Juni 2009): 44-55.

Melani, Agustina. 2014. "5 Saham yang Harganya Jungkir Balik." Liputan 6. http://bisnis.liputan6.com/read/2062334/5-saham-yang-harganyajungkir-balik.

Muhammad, Noor, dan Frank Scrimgeour. 2014. "Stock Returns and Fundamentals in the Australian Market." Asian Journal of Finance \& Accounting 6(1): 27190.

http://www.macrothink.org/journal/index.php/ajfa/article/view/5486.

Najimiyah, Edy Suajana, dan Ni Kadek Sinarwati. 2014. "Pengaruh PBV, PER, DEBT Terhadap Return Saham Industri Real Estate dan Property di BEI 20092013." Jurnal Akuntansi Program S1 2(1).

Papanastasopoulos, Georgios, dan Dimitrios Thomakos. 2016. "Managerial discretion, net operating assets and the cross-section of stock returns: Evidence from European countries." Journal of International Financial Markets, Institutions and Money. http://linkinghub.elsevier.com/retrieve/pii/S1042443116301949.

Papanastasopoulos, Georgios, Dimitrios Thomakos, dan Tao Wang. 2011. "Information in balance sheets for future stock returns: Evidence from net operating assets." International Review of Financial Analysis 20(5): 269-82. http://dx.doi.org/10.1016/j.irfa.2011.06.001.

Puspitasari, Putrillia Dwi, Nyoman Trisna Herawati, dan Ni Luh Gede Erni Sulindawati. 2017. "Pengaruh Ukuran Perusahaan, Total Asset Turnover, Return On Asset, Current Ratio, Debt to Equity Ratio, dan Earning Per Share Terhadap Return Saham." E-Journal S1 Ak Universitas Pendidikan Ganesha 
$7(2017)$.

Putra, Ferdinan Eka, dan Paulus Kindangen. 2016. "Pengaruh Return On Asset (ROA), Net Profit Margin (NPM), Dan Earning Per Share (EPS) Terhadap Return Saham Perusahaan Makanan Dan Minuman Yang Terdaftar Di Bursa Efek Indonesia (Periode 2010-2014)." Jurnal EMBA 4(4): 235-45.

Rostami, Shoeyb, Zeynab Rostami, dan Samin Kohansal. 2016. "The Effect of Corporate Governance Components on Return on Assets and Stock Return of Companies Listed in Tehran Stock Exchange." Procedia Economics and Finance 36(16): 137-46. http://linkinghub.elsevier.com/retrieve/pii/S2212567116300259.

Setiyono, Erik. 2016. "Pengaruh Kinerja Keuangan Dan Ukuran Perusahaan Terhadap Return Saham." 5.

Sherif, Mohamed, dan Darren Leitch. 2017. "Twitter mood, CEO succession announcements and stock returns." Journal of Computational Science. http://linkinghub.elsevier.com/retrieve/pii/S1877750316302113.

Sparta. 2011. “Analisis Validitas Return on Net Operating Asset dan Return on Asset dalam Prediksi Harga Saham pada Industri Manufaktur terdaftar di BEI (Periode 2003-2009)." Keuangan dan Perbankan 8(1): 1-24.

Subramanyam, K R, dan John J Wild. 2011. Analisis Laporan Keuangan. 10 ed. ed. Tim Salemba Empat. Jakarta: Salemba Empat.

Suherman, dan Anwar Siburian. 2013. "Pengaruh Earning Per Share, Debt to Equity Ratio, Return On Equity, dan Price to Book Value Terhadap Return Saham." Jurnal Riset Manajemen Sains Indonesia (JRMSI) 4(2013): 16-30.

Tari Indriani. 2014. “Analisis Pengaruh DER, PBV, Dan PER Terhadap Return Saham Perusahaan Manufaktur Yang Terdaftar di Bursa Efek Indonesia." Universitas Bengkulu.

Ulfa, Ruriana. 2011. "Pengaruh Ukuran Perusahaan, Leverage, Economic Value Added, return On Investment, dan Earning Per Share Terhadap Return yang Diterima Pemegang Saham." UIN Syarif Hidayatullah Jakarta.

W, Ni Nym Ayu Yuliantari, dan I Ketut Sujana. 2014. "Pengaruh Financial Ratio, 
Firm Size, Dan Cash Flow Operating Terhadap Return Share Perusahaan F\&B." E-Journal Akuntansi Universitas Udayana 3(2014): 547-58.

Wallance, Peter, dan John Zinkin. 2005. Corporate Governance. Singapore: John Wiley and Sons.

Wandeca, Jenny Sevi. 2012. "Analisis Pengaruh Pergantian Chief Executive Officer (CEO) Terhadap Praktek Manajemen Laba (Studi Pada Perusahaan BUMN dan Non BUMN di Bursa Efek Indonesia )."

Watson, Anna, Philip Shrives, dan Claire Marston. 2002. "Voluntary Disclosure of Accounting Ratios In The UK." British Accounting Review (2002): 289 ÿ313.

Widyastuti, T R I. 2007. "Pengaruh Karakteristik Perusahaan terhadap Manajemen Laba dan Dampaknya pada Return Saham." Akuntabilitas Jurnal Ilmiah Akuntansi 7(1): 38-44. 